(C) 2022, The Authors. Published by Elsevier Inc. and Fass Inc. on behalf of the American Dairy Science Association ${ }^{\circledR}$. This is an open access article under the CC BY license (http://creativecommons.org/licenses/by/4.0/).

\title{
Methionine supplementation during a hydrogen peroxide challenge alters components of insulin signaling and antioxidant proteins in subcutaneous adipose explants from dairy cows
}

\author{
N. Ma, ${ }^{1,2}$ Y. Liang, ${ }^{1}$ D. N. Coleman, ${ }^{1}$ Y. Li, ${ }^{1,3}$ H. Ding, ${ }^{1,3}$ F. Liu, ${ }^{1,4}$ F. F. Cardoso, ${ }^{1}$ C. Parys,${ }^{5}$ F. C. Cardoso, ${ }^{1}$ \\ X. Shen, ${ }^{2}$ and J. J. Loor ${ }^{1 *}$ \\ ${ }^{1}$ Department of Animal Sciences, Division of Nutritional Sciences, University of Illinois, Urbana 61801 \\ ${ }^{2}$ College of Veterinary Medicine, Nanjing Agricultural University, Nanjing, 210095, Jiangsu, China \\ ${ }^{3}$ Department of Veterinary Medicine, College of Animal Science and Technology, Anhui Agricultural University, Hefei, 230036, Anhui, China \\ ${ }^{4}$ Department of Animal Science and Veterinary Medicine, Henan Agricultural University, Zhengzhou, 450086, Henan, China \\ ${ }^{5}$ Evonik Operations GmbH | Nutrition \& Care, Hanau 63457, Germany
}

\section{ABSTRACT}

Enhanced postruminal supply of methionine (Met) during the peripartal period alters protein abundance of insulin, AA, and antioxidant signaling pathways in subcutaneous adipose tissue (SAT). Whether SAT is directly responsive to supply of Met and can induce molecular alterations is unknown. Our objective was to examine whether enhanced Met supply during an oxidative stress challenge in vitro alters insulin, AA, inflammation, and antioxidant signaling-related protein networks. Four late-lactation Holstein cows (average $27.0 \mathrm{~kg}$ of milk per day) were used for SAT collection. Tissue was incubated in duplicate for $4 \mathrm{~h}$ in a humidified incubator with $5 \% \mathrm{CO}_{2}$ at $37^{\circ} \mathrm{C}$ according to the following experimental design: control medium with an "ideal" profile of essential AA (CTR; Lys:Met 2.9:1), CTR plus $100 \mu M \mathrm{H}_{2} \mathrm{O}_{2}$ (HP), or CTR with greater Met supply plus $100 \mu M \mathrm{H}_{2} \mathrm{O}_{2}$ (HPMET; Lys:Met 2.5:1). Molecular targets associated with insulin signaling, lipolysis, antioxidant nuclear factor, erythroid 2 like 2 (NFE2L2), inflammation, and AA metabolism were determined through reverse-transcription quantitative PCR and western blotting. Data were analyzed using the MIXED procedure of SAS 9.4 (SAS Institute Inc.). Among proteins associated with insulin signaling, compared with CTR, HP led to lower abundance of phosphorylated AKT serine/threonine kinase (p-AKT) and solute carrier family 2 member 4 (SLC2A4; insulininduced glucose transporter). Although incubation with HPMET restored abundance of SLC2A4 to levels in the CTR and upregulated abundance of fatty acid synthase (FASN) and phosphorylated 5'-prime-AMP-

Received March 29, 2021.

Accepted August 25, 2021.

*Corresponding author: jloor@illinois.edu activated protein kinase (p-AMPK), it did not alter p-AKT, which remained similar to HP. Among proteins associated with AA signaling, compared with CTR, challenge with HP led to lower abundance of phosphorylated mechanistic target of rapamycin (p-MTOR), and HPMET did not restore abundance to CTR levels. Among inflammation-related targets studied, incubation with HPMET led to greater protein abundance of nuclear factor kappa B subunit p65 (NFKB-RELA). The response in NFKB observed with HPMET was associated with a marked upregulation of the antioxidant transcription regulator NFE2L2 and the antioxidant enzyme glutathione peroxidase 1 (GPX1). No effects of treatment were detected for mRNA abundance of proinflammatory cytokines or antioxidant enzymes, underscoring the importance of post-transcriptional regulation. Overall, data indicated that short-term challenge with $\mathrm{H}_{2} \mathrm{O}_{2}$ was particularly effective in reducing insulin and AA signaling. Although a greater supply of Met had little effect on those pathways, it seemed to restore the protein abundance of the insulin-induced glucose transporter. Overall, the concomitant upregulation of key inflammation and antioxidant signaling proteins when a greater level of Met was supplemented to oxidant-challenged SAT highlighted the potential role of this AA in regulating the inflammatory response and oxidant status. Further studies should be conducted to assess the role of postruminal supply of Met and other AA in the regulation of immune, antioxidant, and metabolic systems in peripartal cow adipose tissue.

Key words: insulin signaling, adipose tissue, oxidative stress, amino acids

\section{INTRODUCTION}

Dairy cows experience negative energy balance along with systemic inflammation and oxidative stress dur- 
ing the peripartal period (Sordillo and Aitken, 2009; Sordillo and Raphael, 2013; Bradford et al., 2015). Body fat mobilization during negative energy balance helps fill the deficit between intake and requirements in peripartal cows (Loor et al., 2013), but recent evidence indicates that excessive lipolysis could deplete the tissue's antioxidant reserves (Sun et al., 2016; Contreras et al., 2017b). Together, lipolysis, inflammation, and oxidative stress appear closely associated with insulin resistance and could delay recovery of fat depots in dairy cows (McNamara and Huber, 2018). In nonruminants, oxidative stress is considered a major contributing factor of insulin resistance, negatively affecting the control of glucose uptake, protein synthesis, lipogenesis, and aggravating lipolysis (Curtis et al., 2010; Hurrle and Hsu, 2017).

In dairy cows, although a direct link between oxidative stress and insulin resistance has not been concretely established, changes in circulating biomarkers of insulin action in adipose and muscle tissue (Bell and Bauman, 1997; Hayirli, 2006) along with reactive oxygen species (ROS; Bernabucci et al., 2005) especially after calving suggest a potential link. Although the metabolic picture of insulin resistance in nonruminants is markedly different than in ruminants (especially after calving), it is unknown whether increased availability of oxidants can alter insulin signaling or some of its components in bovine adipose tissue.

Methionine, an indispensable AA in lactating cows, not only improves milk protein production (Sun et al., 2016) but enhances innate immune response at the functional and transcriptional level (Zhou et al., 2016; Batistel et al., 2018; Lopreiato et al., 2019). Glutathione (GSH) is a major antioxidant in mammalian cells synthesized from metabolism of Met via the transsulfuration pathway (Martinov et al., 2010). It helps remove ROS via GSH-dependent glutathione peroxidase (GPX)-catalyzed reactions within the cytosol (Lushchak, 2012). Recently, our group reported that feeding rumen-protected Met (RPM) at a rate of approximately $0.09 \%$ of $\mathrm{DM}$ intake to periparturient cows led to greater mRNA (cystathionine- $\beta$-synthase, glutamate-cysteine ligase modifier subunit, glutathione reductase, and GPX1) and protein abundance [GPX1, GPX3, glutathione S-transferase mu 1 (GSTM1), and glutathione S-transferase $\alpha 4$ ] of targets associated with GSH metabolism in subcutaneous adipose tissue (SAT; Liang et al., 2019a,b). Because protected Met also led to greater DMI (Batistel et al., 2017), the precise effect of enhanced circulating concentrations of Met (VailatiRiboni et al., 2019) on tissue-specific mechanisms could not be discerned with certainty.

The main objective of the current study was to generate preliminary data on the effect of increasing Met supplementation on insulin, AA, inflammation, and antioxidant signaling-related molecular networks in explants of SAT from Holstein cows. Target proteins studied were those for which commercially available antibodies have already been used successfully in our laboratory (Elolimy et al., 2019; Liang et al., 2019a,b, 2020). Although ROS encompass molecules such as superoxide anion $\left(\mathrm{O}_{2}^{-}\right)$and hydroxyl radicals $\left(\mathrm{OH}^{-}\right)$that can lead to oxidative stress, we chose hydrogen peroxide $\left(\mathrm{H}_{2} \mathrm{O}_{2}\right)$ to challenge the SAT because data from several studies (Pedernera et al., 2010; Hurrle and Hsu, 2017) support the view that it is an important redox switch. We have used this molecule in several in vitro studies including bovine hepatocytes (Zhang et al., 2020), bovine mammary epithelial cells (Ma et al., 2018a,b,c, 2019), and dairy cow SAT adipocytes (Xu et al., 2021). Our recent work also demonstrated temporal changes in $\mathrm{H}_{2} \mathrm{O}_{2}$ in SAT biopsies during the transition period, supporting the biological relevance of this molecule in the context of redox state (Liang et al., 2019b, 2020).

\section{MATERIALS AND METHODS}

\section{Adipose Explant Culture and Treatments}

All procedures were conducted under protocols approved by the University of Illinois Institutional Animal Care and Use Committee (Urbana; protocol no. 19036). Details of cows used, cell culture protocols, and molecular methods in a similar study involving SAT explants incubated with increased concentrations of Met and Arg during a challenge with $N$-acetyl-D-sphingosine were reported previously (Liang et al., 2021). Briefly, 4 healthy multiparous lactating Holstein cows from the University of Illinois dairy herd were used. Average parity, DIM, and milk yield before slaughter were 4 $\pm 0.4,248 \pm 18 \mathrm{~d}$, and $27.0 \pm 3.5 \mathrm{~kg} / \mathrm{d}$, respectively. Cows were euthanized by captive bolt at the University of Illinois College of Veterinary Medicine diagnostic facilities (Urbana). Samples of SAT from the tail-head of each cow were obtained immediately after slaughter and brought to the laboratory in warm Dulbecco's modified Eagle's medium and Ham's F-12 nutrient mixture (Sigma-Aldrich) containing 1\% penicillin/ streptomycin (Sigma-Aldrich) within $30 \mathrm{~min}$ of collection. Subsequently, tissue (500-600 mg) was trimmed into pieces using a sterile scalpel blade in a sterile Petri dish (catalog no. 101VR20, Thermo Fisher Scientific), and then $200 \mathrm{mg}$ incubated in duplicate in $5 \mathrm{~mL}$ of medium in 6-well plates. Culture media were as follows: control medium with an "ideal" profile of EAA (CTR; Lys:Met 2.9:1; Dong et al., 2018); CTR plus $100 \mu M \mathrm{H}_{2} \mathrm{O}_{2}$ (HP); and CTR with enhanced Met supply (Vailati-Riboni et al., 2019; Dai et al., 2020) plus 
$100 \mu M \mathrm{H}_{2} \mathrm{O}_{2}$ (HPMET; Lys:Met 2.5:1; Table 1). The choice of $\mathrm{H}_{2} \mathrm{O}_{2}$ dose was based on our previous in vitro experiments with bovine mammary epithelial cells (Ma et al., 2018a,b,c) and dairy cow (Xu et al., 2021) or calf (Sun et al., 2019) SAT adipocytes, demonstrating lack of negative effects (e.g., cell viability) of this molecule at concentrations between 0 and $100 \mu M$. Similarly, other studies with nonruminant cells have also revealed no deleterious effects on cell functionality with our chosen dose (Gülden et al., 2010; Hao et al., 2017). Although tissue viability measurements have not been reported in bovine SAT explant studies published to date (e.g., Ingle et al., 1972; McNamara et al., 1995; Lanna and Bauman, 1999; Khan et al., 2013; non-exhaustive tabulation in Supplemental Table S1, https://doi.org/ 10.17632/d5xdrgdkjb.1; Loor, 2021), we used activity of superoxide dismutase (SOD; Xu et al., 2021) as a potential indicator of oxidative stress and cell death (Petrache et al., 2008). Incubations were carried out in a humidified incubator with $5 \% \mathrm{CO}_{2}$ at $37^{\circ} \mathrm{C}$. After $4 \mathrm{~h}$ incubation, SAT explants were transferred from 6-well plates to screw-capped microcentrifuge tubes, snap-frozen in liquid nitrogen, and preserved at $-80^{\circ} \mathrm{C}$ until further analysis. The choice of incubation time length is well within published research with bovine adipose tissue (Supplemental Table S1). In fact, the responsiveness of lactating dairy cow SAT explants in chronic cultures ( $48 \mathrm{~h}$ ) has been reported and validated previously (Lanna and Bauman, 1999).

\section{RNA Isolation, cDNA Synthesis, and Quantitative PCR}

Detailed procedures for measuring target mRNA abundance have been reported in several of our previous publications (Han et al., 2018b; Dai et al., 2020). Briefly, total RNA was isolated from SAT using an miRNeasy kit (catalog no. 217004, Qiagen) following the manufacturer's instruction. Concentration of RNA was measured with a NanoDrop ND-1000 spectrophotometer (Thermo Fisher Scientific). Quality of RNA samples was further ascertained with an Agilent 2100 Bioanalyzer (Agilent Technologies). Average RNA integrity number of samples used was $9.47 \pm 0.21$. Total RNA (100 ng/ $\mu \mathrm{L}$ RNase-free water) was reverse-transcribed to cDNA. After 1:4 dilution, cDNA was used for quantitative (q)PCR. The qPCR system included SYBR Green Fast Mix ROX (catalog no. 101414-280, Quanta Biosciences), forward and reverse primers, and nuclease-free water. The qPCR was operated in an ABI Prism 7900 HT SDS instrument (Applied Biosystems). Ribosomal protein S9, GAPDH, and $A C T B$ were chosen as internal control genes to normalize mRNA data by their geometric mean. For each gene, normalized qPCR data are presented as fold-change relative to CTR. To estimate standard errors for CTR data and prevent biases in statistical analysis, normalized data were transformed to obtain a perfect mean of 1.0, leaving the proportional difference between the biological replicate. The same proportional change was calculated for the treatment groups to obtain a fold-change relative to CTR. All reactions were run in triplicate. Gene symbols, primer information, and qPCR performance are included in Supplemental Tables S2 and S3 (https:/ /doi.org/10.17632/d5xdrgdkjb.1; Loor, 2021).

\section{Western Blotting}

Details of the western blotting procedure were reported previously (Batistel et al., 2017; Liang et al., 2021). Briefly, approximately $100 \mathrm{of} \mathrm{mg}$ adipose tissue was homogenized in $1 \mathrm{~mL}$ of RIPA Lysis and Extraction Buffer (catalog no. 89900, Thermo Fisher) containing Halt protease and phosphatase inhibitor cocktail (100×, catalog no. 78442; Thermo Fisher Scientific) for $60 \mathrm{~s}$ and then placed on ice for $20 \mathrm{~min}$. The lysate was centrifuged at $14,000 \times g$ for $15 \mathrm{~min}$ at $4^{\circ} \mathrm{C}$. Protein concentration of the supernatant was determined using a Pierce Bicinchoninic Acid Protein Assay Kit (catalog no. 23227, Thermo Fisher Scientific). Protein samples were denatured by heating at $95^{\circ} \mathrm{C}$ for $5 \mathrm{~min}$ before loading $20 \mu \mathrm{L}$ of protein into each lane of $4 \%$ to $20 \%$ Mini-Protean TGX precast gels (catalog no. 4561093, Bio-Rad) and transferred onto a polyvinylidene difluoride membrane (catalog no. 1620261, Bio-Rad) in a

Table 1. Amino acid composition of control medium with an "ideal" profile of EAA (CTR; Lys:Met 2.9:1), CTR plus $100 \mu M \mathrm{H}_{2} \mathrm{O}_{2}$ (HP), and CTR with added Met plus $100 \mu M \mathrm{H}_{2} \mathrm{O}_{2}$ (HPMET; Lys:Met 2.5:1)

\begin{tabular}{lccc}
\hline & \multicolumn{3}{c}{ Treatment $^{1}$} \\
\cline { 2 - 4 } Item $(\mu \mathrm{g} / \mathrm{mL})$ & CTR & HP & HPMET \\
\hline L-Lysine & 175 & 175 & 175 \\
Lys:Met & $2.9: 1$ & $2.9: 1$ & $2.5: 1$ \\
L-Methionine & 60 & 60 & 70 \\
L-Arginine & 84 & 84 & 84 \\
L-Histidine & 74 & 74 & 74 \\
L-Isoleucine & 121 & 121 & 121 \\
L-Leucine & 206 & 206 & 206 \\
L-Phenylalanine & 93 & 93 & 93 \\
L-Threonine & 97 & 97 & 97 \\
L-Tryptophan & 16 & 16 & 16 \\
L-Valine & 142 & 142 & 142 \\
\hline
\end{tabular}

${ }^{1} \mathrm{CTR}$ ratio of EAA was as follows: Lys:Met $=2.9$, Lys:Thr $=1.8$, Lys:His $=2.38$, Lys:Val $=1.23$, and Thr:Phe $=1.05$, according to published recommendations (NRC, 2001; Haque et al., 2012) and our previous studies (Li et al., 2016; Vailati-Riboni et al., 2019). The level of added Met in the HPMET treatment was according to our previous work (Dong et al., 2018). 
Trans-Blot SD Semi-Dry Electrophoretic Transfer Cell (catalog no. 170-3940, Bio-Rad). After blocking with $5 \%$ nonfat milk in $1 \times$ Tris-buffered saline $(1 \times$ TBST) at room temperature for $2 \mathrm{~h}$, the membrane was incubated with primary antibodies (Supplemental Table S4; https://doi.org/10.17632/d5xdrgdkjb .1; Loor, 2021) overnight at $4^{\circ} \mathrm{C}$. In an attempt to assess molecular responses associated with cell death, we tested primary antibodies for HSP70 (catalog no. 4872, Cell Signaling Technology Inc.) and haptoglobin (sc-69782, Santa Cruz Biotechnology Inc.) at dilutions of 1:500 and 1:250, but were unsuccessful in detecting a signal. The membrane was washed with $1 \times$ TBST, and incubated with HRP goat anti-rabbit IgG as the secondary antibody (catalog no. 7074S, Cell Signaling Technology, diluted to 1:1,000) for $1 \mathrm{~h}$. Visualization of target proteins was performed using the Clarity Western ECL Substrate (catalog no. 170-5060, Bio-Rad). Each protein was normalized against the expression of GAPDH, and data are reported as relative expression. The enhanced chemiluminescence signals were acquired using an imaging system (ChemiDoc MP, Bio-Rad), and the intensities of the bands were analyzed using Image-Pro Plus 6.0 software (Bio-Rad). All information for primary antibodies is listed in Supplemental Table S3.

\section{SOD in SAT}

Superoxide dismutase activity (catalog no. 706002, Cayman Chemical) was analyzed in SAT using a commercial kit following the manufacturer's protocols. We have previously used this kit with SAT biopsies from peripartal cows (Liang et al., 2019b).

\section{Statistical Analysis}

Normalized data (western blotting, reverse-transcription PCR) are reported as fold change relative to CTR. To estimate standard errors in CTR and prevent biases in statistical analysis, normalized data were transformed to obtain a perfect mean of 1.0, leaving the proportional difference between the biological replicate. The same proportional difference was calculated for the HP and HPMET data to obtain a fold change relative to control. The final data set was analyzed using the MIXED procedure of SAS 9.4 (SAS Institute Inc.) according to the following model with repeated measures:

$$
Y_{j}=\mu+M_{j}+e_{j},
$$

where $Y_{j}=$ dependent, continuous variable, $\mu=$ overall mean, $\mathrm{M}_{\mathrm{j}}=$ fixed effect of treatment $(\mathrm{j}=\mathrm{CTR}, \mathrm{HP}$, or HPMET), and $e_{j}=$ residual error. Cow was the random effect. When treatment was significant, least squares means separation between groups was performed using the PDIFF statement with Tukey adjustment. Normality of the residuals was checked with normal probability and box plots, and homogeneity of variances was checked with plots of residuals versus predicted values. Significance was set at $P \leq 0.05$.

\section{RESULTS}

\section{Abundance of Insulin and AA Metabolism- Related Proteins}

Treatment had a significant effect (Table 2) on the protein abundance of phosphorylated $(\mathbf{p})$-AKT $(P=$ $0.05)$, p-MTOR $(P<0.01)$, phosphorylated 5'-primeAMP-activated protein kinase (p-AMPK; $P=0.05$ ), and fatty acid synthase (FASN; $P=0.05)$. Compared with CTR, abundance of p-AKT $(P=0.05)$ and pMTOR $(P<0.01)$ was downregulated by $\mathrm{H}_{2} \mathrm{O}_{2}$ treatment. Compared with HP, enhanced Met supply resulted in greater protein abundance of p-AMPK and FASN. Additionally, treatment tended to influence the protein abundance of S-adenosylmethionine sensor upstream of TORC1 (SAMTOR; $P=0.08$ ) and hormone-sensitive lipase (LIPE; $P=0.10$ ). Treatment had a significant effect on the insulin-induced glucose transport carrier, solute carrier family 2 member 4 (SLC2A4; $P=0.05$; Table 2). Compared with CTR, HP led to downregulation of SLC2A4, and supply of Met restored protein abundance to the levels detected with CTR.

\section{Abundance of Immune Response Proteins and Genes}

Protein abundance of nuclear factor kappa B subunit p65 (RELA; $P=0.02$; Table 3) was significantly affected by treatment. Although HP had no effect, protein abundance of RELA was greater in response to HPMET. At the mRNA level, abundance of the cytokines $I L 6, T N F, I L 10$, and $I L 1 B$ was not affected by treatment (all $P>0.10$; Table 4).

\section{Abundance of Antioxidant Signaling and Met Metabolism-Related Proteins}

Treatment affected the protein abundance of GPX1, the antioxidant transcription regulator nuclear factor, erythroid 2 like 2 (NFE2L2), and the cytosolic oxidant 
Table 2. Response in the abundance of proteins associated with insulin and AA signaling, transsulfuration, and nutrient transport in subcutaneous adipose tissue (SAT; $\mathrm{n}=4$ /treatment) cultured in medium with an "ideal" profile of EAA (CTR; Lys:Met 2.9:1), SAT incubated with CTR plus $100 \mu M \mathrm{H}_{2} \mathrm{O}_{2}$ (HP), or SAT incubated with CTR plus enhanced Met supply plus $100 \mu M \mathrm{H}_{2} \mathrm{O}_{2}$ (HPMET; Lys:Met 2.5:1); values are means expressed relative to CTR, which was set to 1.0

\begin{tabular}{|c|c|c|c|c|c|}
\hline \multirow[b]{2}{*}{ Item $^{1}$} & \multicolumn{3}{|c|}{ Treatment $^{2}$} & \multirow[b]{2}{*}{ SEM } & \multirow[b]{2}{*}{$P$-value } \\
\hline & CTR & $\mathrm{HP}$ & HPMET & & \\
\hline \multicolumn{6}{|c|}{ Insulin signaling } \\
\hline $\mathrm{p}-\mathrm{AKT}$ & $1.00^{\mathrm{a}}$ & $0.26^{\mathrm{b}}$ & $0.27^{\mathrm{b}}$ & 0.21 & 0.05 \\
\hline PPARG & 1.00 & 0.56 & 0.87 & 0.16 & 0.25 \\
\hline $\mathrm{p}-\mathrm{ACACA}$ & 1.00 & 1.24 & 0.71 & 0.21 & 0.24 \\
\hline FASN & $1.00^{\mathrm{b}}$ & $0.93^{\mathrm{b}}$ & $1.78^{\mathrm{a}}$ & 0.21 & 0.05 \\
\hline p-AMPK & $1.00^{\mathrm{b}}$ & $0.81^{\mathrm{b}}$ & $2.76^{\mathrm{a}}$ & 0.47 & 0.05 \\
\hline LIPE & 1.00 & 0.54 & 1.02 & 0.15 & 0.10 \\
\hline \multicolumn{6}{|c|}{ AA signaling } \\
\hline p-MTOR & $1.00^{\mathrm{a}}$ & $0.40^{\mathrm{b}}$ & $0.20^{\mathrm{b}}$ & 0.08 & $<0.01$ \\
\hline SAMTOR & 1.00 & 0.48 & 0.41 & 0.17 & 0.08 \\
\hline \multicolumn{6}{|c|}{ Transsulfuration } \\
\hline CBS & 1.00 & 0.50 & 0.76 & 0.32 & 0.59 \\
\hline \multicolumn{6}{|c|}{ Glucose and AA transport } \\
\hline SLC1A3 & 1.00 & 0.70 & 0.90 & 0.30 & 0.87 \\
\hline SLC2A4 & $1.00^{\mathrm{ab}}$ & $0.48^{\mathrm{b}}$ & $1.23^{\mathrm{a}}$ & 0.19 & 0.05 \\
\hline
\end{tabular}

${ }^{\mathrm{a}, \mathrm{b}}$ Means between treatments with different lowercase superscripts differ $(P \leq 0.05)$.

${ }^{1} \mathrm{CBS}=$ cystathionine $\beta$-synthase FASN $=$ fatty acid synthase $;$ LIPE $=$ hormone-sensitive lipase; $\mathrm{p}$-ACACA = phosphorylated acetyl-CoA carboxylase $\alpha$; p-AKT = phosphorylated AKT serine/threonine kinase; p-AMPK $=$ phosphorylated 5'-prime-AMP-activated protein kinase; -MTOR $=$ phosphorylated mechanistic target of rapamycin; PPARG = peroxisome proliferator activated receptor gamma; SAMTOR $=$ S-adenosylmethionine sensor upstream of TORC1; SLC1A3 = solute carrier family 1 member 3; SLC2A4 = solute carrier family 2 member 4 (GLUT4).

${ }^{2}$ Each protein was first normalized against the expression of GAPDH before calculating differences relative to CTR (which was set to 1.0).

product detoxification enzyme GSTM1 (Table 3). Compared with the HP cultures, enhanced supply of Met led to greater NFE2L2 $(P=0.03)$ and GPX1 $(P=$ $0.05)$ but lower GSTM1 $(P=0.02)$ protein abundance.

\section{SOD Activity}

Although activity of SOD was numerically lower $(\sim 75 \%)$ with $\mathrm{HP}(0.53 \pm 0.06 \mathrm{U} / \mathrm{mg}$ of protein $)$ and

Table 3. Response in the abundance of inflammation- and antioxidant-related proteins in subcutaneous adipose tissue (SAT; $n=4$ /treatment) cultured in medium with an "ideal" profile of EAA (CTR; Lys:Met 2.9:1), SAT incubated with CTR plus $100 \mu \mathrm{M} \mathrm{H}_{2} \mathrm{O}_{2}$ (HP), or SAT incubated with CTR plus enhanced Met supply plus $100 \mu \mathrm{M} \mathrm{H}_{2} \mathrm{O}_{2}$ (HPMET; Lys:Met 2.5:1); values are means expressed relative to CTR, which was set to 1.0

\begin{tabular}{llllll}
\hline & \multicolumn{3}{c}{ Treatment $^{2}$} \\
\cline { 3 - 3 } Item $^{1}$ & CTR & HP & HPMET & SEM & P-value \\
\hline Inflammation & $1.00^{\mathrm{b}}$ & $0.64^{\mathrm{b}}$ & $1.83^{\mathrm{a}}$ & 0.25 & 0.02 \\
$\quad$ RELA & & & & & \\
$\quad$ Antioxidant signaling & $1.00^{\mathrm{b}}$ & $0.99^{\mathrm{b}}$ & $3.82^{\mathrm{a}}$ & 0.65 & 0.03 \\
$\quad$ NFE2L2 & 1.00 & 1.61 & 2.01 & 0.35 & 0.27 \\
$\quad$ KEAP1 & $1.00^{\mathrm{b}}$ & $0.60^{\mathrm{b}}$ & $1.95^{\mathrm{a}}$ & 0.28 & 0.05 \\
$\quad$ Glutathione metabolism & $0.98^{\mathrm{a}}$ & $0.79^{\mathrm{a}}$ & $0.43^{\mathrm{b}}$ & 0.11 & 0.02 \\
$\quad$ GPX1 & &
\end{tabular}

${ }^{a, b}$ Means between treatment with different lowercase superscripts differ $(P \leq 0.05)$.

${ }^{1} \mathrm{GPX} 1$ = glutathione peroxidase $1 ;$ GSTM1 = glutathione S-transferase mu 1 ; KEAP1 = kelch-like ECHassociated protein 1; NFE2L2 = nuclear factor, erythroid 2 like 2; RELA = nuclear factor kappa B subunit p65.

${ }^{2}$ Each protein was first normalized against the expression of GAPDH before calculating differences relative to CTR (which was set to 1.0). 
HPMET $(0.42 \pm 0.06 \mathrm{U} \mathrm{mg}$ of protein) relative to $\mathrm{CTR}$ $(0.61 \pm 0.06 \mathrm{U} / \mathrm{mg}$ of protein $)$, no statistical effect was detected $(P=0.19)$.

\section{DISCUSSION}

Work from our laboratory using transcriptomics and bioinformatics on adipose tissue from peripartal or dry cows (Moisá et al., 2017; Minuti et al., 2020) has uncovered several biologically relevant pathways, of which AA signaling via MTOR seems particularly important, given its role in coordinating aspects of tissue protein synthesis as a function of AA availability. In nonruminants, mechanistic target of rapamycin $\mathrm{C} 1$ (MTORC1) silencing contributes to the manifestation of some stress-related phenotypes, suggesting that signaling through this kinase could regulate aspects of adipose tissue function (Cai et al., 2016). For instance, adipocyte MTORC1 deficiency in mice markedly decreased lipid storage in adipose tissue and induced hepatic steatosis along with insulin resistance (Chimin et al., 2017). Activation of MTOR can upregulate mitochondrial biogenesis and oxidative metabolism (Cunningham et al., 2007), and ROS production contributes to the inhibition of MTOR signaling (Zhao et al., 2017).

Although $100 \mu M \mathrm{H}_{2} \mathrm{O}_{2}$ did not affect the proliferation of primary bovine mammary epithelial cells (Ma et al., 2018a) or other mammalian cell lines within a 4-h incubation (Davies, 1999; Gülden et al., 2010), the observed decrease in protein abundance of AKT and MTOR in adipose explants suggested that intracellular oxidants might impair some aspects of normal bovine adipose function. This idea is partly supported by data from SAT adipocytes isolated from biopsies of clinically healthy dairy cows at 17 DIM (Xu et al., 2021). In that study, relative to the control, a linear increase was observed in malondialdehyde (MDA) and ROS concentrations and a decrease in SOD and glutathione peroxidase (GPX) activity in adipocytes incubated with $100 \mu M \mathrm{H}_{2} \mathrm{O}_{2}$. However, although those enzymes clearly were negatively affected, cell viability actually peaked at $100 \mu M \mathrm{H}_{2} \mathrm{O}_{2}$, a response that we surmised was due to upregulation of the abundance of SOD and GST proteins (Xu et al., 2021). Our own in vivo data on SOD revealed little change in activity around parturition in SAT despite the gradual increases in ROS (Liang et al., 2019b). Although the present study was performed with SAT from late-lactation cows, these data led us to speculate that SAT can mount a robust antioxidant response driven in no small part via molecular changes for several proteins.

At least in nonruminants, insulin signaling controls glucose absorption, lipogenesis, lipolysis, and protein synthesis (Kenéz et al., 2019), all of which play vital roles in adipose tissue metabolism. A transient state of insulin resistance around parturition prevents peripheral tissues from using glucose, to guarantee glucose supply for the mammary gland (Contreras et al.,

Table 4. mRNA abundance of inflammation, antioxidant, and glutathione metabolism-related genes in subcutaneous adipose tissue (SAT; $\mathrm{n}=4$ /treatment) cultured in medium with an "ideal" profile of EAA (CTR; Lys:Met 2.9:1), SAT incubated with CTR plus $100 \mu M \mathrm{H}_{2} \mathrm{O}_{2}$ (HP), or SAT incubated with CTR plus enhanced Met supply plus $100 \mu \mathrm{M} \mathrm{H}_{2} \mathrm{O}_{2}$ (HPMET; Lys:Met 2.5:1); values are means expressed relative to CTR, which was set to 1.0

\begin{tabular}{lccccc}
\hline & \multicolumn{3}{c}{ Treatment $^{2}$} \\
\cline { 2 - 3 } Item $^{1}$ & CTR & HP & HPMET & SEM & P-value \\
\hline Inflammation & & & & & \\
IL6 & 1.00 & 0.90 & 0.76 & 0.11 & 0.34 \\
TNF & 1.00 & 0.44 & 0.51 & 0.27 & 0.33 \\
IL10 & 1.00 & 0.53 & 0.57 & 0.16 & 0.15 \\
IL1B & 1.00 & 0.52 & 0.48 & 0.27 & 0.37 \\
Antioxidant enzymes & & & & & 0.06 \\
SOD1 & 1.00 & 1.04 & 0.85 & 0.19 & 0.47 \\
SOD2 & 1.00 & 0.71 & 0.68 & 0.10 & 0.07 \\
CAT & 1.00 & 1.40 & 1.16 & 0.04 & 0.04 \\
GCLC & $1.00^{\mathrm{a}}$ & $0.84^{\mathrm{b}}$ & $0.81^{\mathrm{b}}$ & 0.10 & 0.25 \\
GCLM & 1.00 & 0.97 & 0.76 & & \\
\hline
\end{tabular}

${ }_{\mathrm{a}, \mathrm{b}}$ Means between treatment with different lowercase superscripts differ $(P \leq 0.05)$.

${ }^{1} C A T=$ catalase; $G C L C=$ glutamate-cysteine ligase catalytic subunit; $G C L M=$ glutamate-cysteine ligase modifier subunit; $I L 6=$ interleukin 6 ; IL10 = interleukin $10 ; I L 1 B=$ interleukin $1 \beta ; S O D 1=$ superoxide dismutase 1; SOD2 = superoxide dismutase 2 , mitochondrial; $T N F=$ tumor necrosis factor.

${ }^{2}$ Ribosomal protein $\mathrm{S} 9, G A P D H$, and $A C T B$ were chosen as internal control genes to normalize mRNA data after calculating their geometric mean. For each gene, treatment differences were calculated relative to CTR (which was set to 1.0). 
2017a). This physiological state is characterized by low insulin concentration in plasma and reduced insulin responsiveness in skeletal and adipose tissue (Bell and Bauman, 1997; Etherton and Bauman, 1998). Lower insulin responsiveness postpartum versus prepartum, assessed via glucose tolerance tests, underscored the state of insulin resistance (Holtenius et al., 2003). The fact that downregulation of SLC2A4 caused by oxidative stress dampened the sensitivity of adipose tissue to insulin (Hurrle and Hsu, 2017) led us to speculate that $\mathrm{H}_{2} \mathrm{O}_{2}$ challenge might have caused oxidative stress and a subsequent decrease in protein abundance of SLC2A4.

The AMP-activated protein kinase (AMPK) plays an important role in controlling cellular energy homeostasis, partly through its role in altering glucose uptake via enhancing the translocation of intracellular storage vesicles of SLC2A4 to the plasma membrane (Hardie et al., 2012). Thus, upregulation of p-AMPK in response to enhanced Met supply partly explained the increase in protein abundance of SLC2A4. Activation of AMPK reduced de novo fatty acid synthesis by downregulating $A C A C A$ and FASN mRNA in bovine mammary epithelial cells (McFadden and Corl, 2009). Thus, the upregulation of p-AMPK and FASN in response to Met supply suggested this AA might contribute to de novo fatty acid synthesis independent of the AMPK pathway. Whether other AA in the culture medium induced a lipogenic effect, as by feeding the TCA cycle, cannot be discerned. Future research is warranted to investigate the mechanisms whereby Met and other AA may participate in the regulation of lipid synthesis in bovine adipose tissue.

At least in nonruminants, nuclear factor, erythroid 2 like 2, a master regulator of cellular redox homeostasis, controls the transcription of many antioxidant enzymes such as $\mathrm{SOD}$, glutathione peroxidase, $C A T, \mathrm{NAD}(\mathrm{P}) \mathrm{H}$ dehydrogenase 1, and GSH metabolism-related enzymes (e.g., GSR, GPX1, GPX2, and GPX3) (Lushchak, 2012). Kelch-like ECH-associated protein 1 (KEAP1), a negative regulator of NFE2L2, prevents movement of the NFE2L2 protein into the nucleus of the cell, inhibiting its activity. Greater RPM supplementation upregulated NFE2L2 and downregulated KEAP1 in bovine mammary tissue during the periparturient period (Han et al., 2018a). In addition, compared with controls, RPM led to greater abundance of p-NFE2L2 in SAT at $30 \mathrm{~d}$ after parturition (Liang et al., 2019b). Thus, available data suggest that increased postruminal Met supply might alter the interactions between NFE2L2 and KEAP1, with a net result of enhancing the antioxidant activity of the tissue. Such an effect helps explain the observed upregulation of NFE2L2 in SAT explants.
Glutamate-cysteine ligase catalytic subunit (GCLC) is the rate-limiting enzyme in GSH synthesis ( $\mathrm{Lu}$, 2013). Thus, downregulation of $G C L C$ caused by $\mathrm{H}_{2} \mathrm{O}_{2}$ stimulation of adipose explants suggested that $\mathrm{H}_{2} \mathrm{O}_{2}$ might reduce GSH synthesis and contribute to enhancing the oxidant status. Glutathione S-transferase mu 1 (GSTM1), one of the GSH S-transferases, catalyzes the conjugation of GSH to electrophilic compounds (Han et al., 2018b), which led us to speculate that greater protein abundance of GSTM1 in bovine SAT from cows fed RPM was indicative of a reduction in oxidant status within the tissue (Liang et al., 2019b). As such, the observed downregulation of GSTM1 in explants receiving added Met was somewhat unexpected. It could be that inherent differences in the responsiveness of SAT around parturition compared with later in lactation (Contreras et al., 2017b) account for some of these differences.

The complex formed by NF- $\kappa \mathrm{B}$ and RELA mediates the transcription of pro-inflammatory cytokines such as IL1B, IL6, and TNF (Vallabhapurapu and Karin, 2009). In a previous in vitro study, we demonstrated that greater supply of Met reduced pro-inflammatory responses in bovine mammary epithelial cells exposed to a short-term challenge with lipopolysaccharide (Dai et al., 2020). Although the upregulation of RELA in response to Met supply in explants challenged with $\mathrm{H}_{2} \mathrm{O}_{2}$ appears paradoxical given the positive effect of this AA on NFE2L2 and GPX1, it could be that activation of the immune response under the conditions of the study represented a homeostatic response (Contreras et al., 2017b). Our previous work and others have clearly demonstrated that immune responsiveness of SAT is an inherent feature of the tissue, which serves key functions such as allowing proper remodeling (Vailati-Riboni et al., 2016; Moisá et al., 2017; Lopreiato et al., 2018).

As in our recent paper with SAT explants (Liang et al., 2021), some limitations of the present study should be acknowledged. First, by design, the present study narrowly focused on only a few components of insulin, AA, inflammation, and antioxidant signaling-related pathways during $\mathrm{H}_{2} \mathrm{O}_{2}$ stimulation under basal conditions. Thus, we could not clarify the effect of insulin. Second, in spite of its use in many published bovine cell studies (e.g., Xu et al., 2021), a supraphysiological concentration of a single pro-oxidant $\left(\mathrm{H}_{2} \mathrm{O}_{2}\right)$ under basal conditions (i.e., with no insulin challenge) was used. Thus, responses detected might not adequately reflect the fact that SAT might experience a challenge from more than one pro-oxidant molecule in vivo. Lastly, SAT was obtained from late-lactation cows, which cannot reflect the responsiveness of tissue from peripartal cows. 


\section{CONCLUSIONS}

Although direct measures of oxidant and antioxidant molecules were not performed, overall, the responses observed indicated that exogenous $\mathrm{H}_{2} \mathrm{O}_{2}$ was able to alter tissue oxidant status. In fact, the short-term stimulation of adipose tissue with $\mathrm{H}_{2} \mathrm{O}_{2}$ had a negative influence on some of the components of insulin signaling that were chosen for study. It did so without negative effects on tissue SOD activity, which in studies with isolated adipocytes has proven sensitive to $\mathrm{H}_{2} \mathrm{O}_{2}$. Increasing the supply of Met attenuated the decrease in abundance of insulin signaling-related proteins and seemed to enhance NFE2L2 and GSH-related antioxidant responses. Further in vivo research is warranted to investigate the role of Met and other AA in regulating immune, antioxidant, and metabolic systems in bovine adipose tissue. Such work should encompass not only molecular tools but also mass spectrometry, isotopic tracing technologies, and assays for key enzyme activities in those pathways.

\section{ACKNOWLEDGMENTS}

N. Ma, Y. Liang, and H. Ding received scholarships from the China Scholarship Council (Beijing) to undertake $\mathrm{PhD}$ training at the University of Illinois at Urbana-Champaign. Y. Li and F. Liu received postdoctoral scholarships from the China Scholarship Council (Beijing) to undertake $\mathrm{PhD}$ training at the University of Illinois at Urbana-Champaign. The authors have not stated any conflicts of interest.

\section{REFERENCES}

Batistel, F., A. S. Alharthi, L. Wang, C. Parys, Y. X. Pan, F. C. Cardoso, and J. J. Loor. 2017. Placentome nutrient transporters and mammalian target of rapamycin signaling proteins are altered by the methionine supply during late gestation in dairy cows and are associated with newborn birth weight. J. Nutr. 147:1640-1647. https://doi.org/10.3945/jn.117.251876.

Batistel, F., J. M. Arroyo, C. I. M. Garces, E. Trevisi, C. Parys, M. A. Ballou, F. C. Cardoso, and J. J. Loor. 2018. Ethyl-cellulose rumen-protected methionine alleviates inflammation and oxidative stress and improves neutrophil function during the periparturient period and early lactation in Holstein dairy cows. J. Dairy Sci. 101:480-490. https://doi.org/10.3168/jds.2017-13185.

Bell, A. W., and D. E. Bauman. 1997. Adaptations of glucose metabolism during pregnancy and lactation. J. Mammary Gland Biol. Neoplasia 2:265-278. https://doi.org/10.1023/A:1026336505343.

Bernabucci, U., B. Ronchi, N. Lacetera, and A. Nardone. 2005. Influence of body condition score on relationships between metabolic status and oxidative stress in periparturient dairy cows. J. Dairy Sci. 88:2017-2026. https://doi.org/10.3168/jds.S0022 -0302(05) 72878-2.

Bradford, B. J., K. Yuan, J. K. Farney, L. K. Mamedova, and A. J. Carpenter. 2015. Invited review: Inflammation during the transition to lactation: New adventures with an old flame. J. Dairy Sci. 98:6631-6650. https://doi.org/10.3168/jds.2015-9683.
Cai, H., L. Q. Dong, and F. Liu. 2016. Recent advances in adipose mTOR signaling and function: Therapeutic prospects. Trends Pharmacol. Sci. 37:303-317. https://doi.org/10.1016/j.tips.2015 .11 .011 .

Chimin, P., M. L. Andrade, T. Belchior, V. A. Paschoal, J. Magdalon, A. S. Yamashita, E. Castro, A. Castoldi, A. B. Chaves-Filho, M. Y. Yoshinaga, S. Miyamoto, N. O. Camara, and W. T. Festuccia. 2017. Adipocyte mTORC1 deficiency promotes adipose tissue inflammation and NLRP3 inflammasome activation via oxidative stress and de novo ceramide synthesis. J. Lipid Res. 58:1797-1807. https://doi.org/10.1194/jlr.M074518.

Contreras, G. A., C. Strieder-Barboza, J. de Souza, J. Gandy, V. Mavangira, A. L. Lock, and L. M. Sordillo. 2017a. Periparturient lipolysis and oxylipid biosynthesis in bovine adipose tissues. PLoS One 12:e0188621. https://doi.org/10.1371/journal.pone.0188621.

Contreras, G. A., C. Strieder-Barboza, and W. Raphael. 2017b. Adipose tissue lipolysis and remodeling during the transition period of dairy cows. J. Anim. Sci. Biotechnol. 8:41. https://doi.org/10 .1186/s40104-017-0174-4.

Cunningham, J. T., J. T. Rodgers, D. H. Arlow, F. Vazquez, V. K. Mootha, and P. Puigserver. 2007. mTOR controls mitochondrial oxidative function through a YY1-PGC-1 $\alpha$ transcriptional complex. Nature 450:736-740. https://doi.org/10.1038/nature06322.

Curtis, J. M., P. A. Grimsrud, W. S. Wright, X. Xu, R. E. Foncea D. W. Graham, J. R. Brestoff, B. M. Wiczer, O. Ilkayeva, K. Cianflone, D. E. Muoio, E. A. Arriaga, and D. A. Bernlohr. 2010. Downregulation of adipose glutathione S-transferase A4 leads to increased protein carbonylation, oxidative stress, and mitochondrial dysfunction. Diabetes 59:1132-1142. https://doi.org/10.2337/ db09-1105.

Dai, H., D. N. Coleman, L. Hu, I. Martinez-Cortes, M. Wang, C. Parys, X. Shen, and J. J. Loor. 2020. Methionine and arginine supplementation alter inflammatory and oxidative stress responses during lipopolysaccharide challenge in bovine mammary epithelial cells in vitro. J. Dairy Sci. 103:676-689. https://doi.org/10.3168/ jds.2019-16631.

Davies, K. J. 1999. The broad spectrum of responses to oxidants in proliferating cells: A new paradigm for oxidative stress. IUBMB Life 48:41-47. https://doi.org/10.1080/713803463.

Dong, X., Z. Zhou, B. Saremi, A. Helmbrecht, Z. Wang, and J. J. Loor. 2018. Varying the ratio of Lys:Met while maintaining the ratios of Thr:Phe, Lys:Thr, Lys:His, and Lys:Val alters mammary cellular metabolites, mammalian target of rapamycin signaling, and gene transcription. J. Dairy Sci. 101:1708-1718. https://doi.org/ $10.3168 /$ jds.2017-13351.

Elolimy, A. A., E. Abdel-Hamied, L. Hu, J. C. McCann, D. W. Shike, and J. J. Loor. 2019. Rapid Communication: Residual feed intake in beef cattle is associated with differences in protein turnover and nutrient transporters in ruminal epithelium. J. Anim. Sci. 97:2181-2187. https://doi.org/10.1093/jas/skz080.

Etherton, T. D., and D. E. Bauman. 1998. Biology of somatotropin in growth and lactation of domestic animals. Physiol. Rev. 78:745761. https://doi.org/10.1152/physrev.1998.78.3.745.

Gülden, M., A. Jess, J. Kammann, E. Maser, and H. Seibert. 2010 Cytotoxic potency of $\mathrm{H}_{2} \mathrm{O}_{2}$ in cell cultures: Impact of cell concentration and exposure time. Free Radic. Biol. Med. 49:1298-1305. https://doi.org/10.1016/j.freeradbiomed.2010.07.015.

Han, L., F. Batistel, Y. Ma, A. S. M. Alharthi, C. Parys, and J. J. Loor. 2018a. Methionine supply alters mammary gland antioxidant gene networks via phosphorylation of nuclear factor erythroid 2-like 2 (NFE2L2) protein in dairy cows during the periparturient period. J. Dairy Sci. 101:8505-8512. https://doi.org/10.3168/jds .2017-14206.

Han, L. Q., Z. Zhou, Y. Ma, F. Batistel, J. S. Osorio, and J. J. Loor. 2018b. Phosphorylation of nuclear factor erythroid 2-like 2 (NFE2L2) in mammary tissue of Holstein cows during the periparturient period is associated with mRNA abundance of antioxidant gene networks. J. Dairy Sci. 101:6511-6522. https://doi.org/10 .3168/jds.2017-14257.

Hao, T., J. Li, F. Yao, D. Dong, Y. Wang, B. Yang, and C. Wang. 2017. Injectable fullerenol/alginate hydrogel for suppression of 
oxidative stress damage in brown adipose-derived stem cells and cardiac repair. ACS Nano 11:5474-5488. https://doi.org/10.1021/ acsnano.7b00221.

Haque, M. N., H. Rulquin, A. Andrade, P. Faverdin, J. L. Peyraud, and S. Lemosquet. 2012. Milk protein synthesis in response to the provision of an "ideal" amino acid profile at 2 levels of metabolizable protein supply in dairy cows. J. Dairy Sci. 95:5876-5887. https://doi.org/10.3168/jds.2011-5230.

Hardie, D. G., F. A. Ross, and S. A. Hawley. 2012. AMPK: A nutrient and energy sensor that maintains energy homeostasis. Nat. Rev. Mol. Cell Biol. 13:251-262. https://doi.org/10.1038/nrm3311.

Hayirli, A. 2006. The role of exogenous insulin in the complex of hepatic lipidosis and ketosis associated with insulin resistance phenomenon in postpartum dairy cattle. Vet. Res. Commun. 30:749774. https://doi.org/10.1007/s11259-006-3320-6.

Holtenius, K., S. Agenäs, C. Delavaud, and Y. Chilliard. 2003. Effects of feeding intensity during the dry period. 2. Metabolic and hormonal responses. J. Dairy Sci. 86:883-891. https://doi.org/10 .3168/jds.S0022-0302(03)73671-6.

Hurrle, S., and W. H. Hsu. 2017. The etiology of oxidative stress in insulin resistance. Biomed. J. 40:257-262. https://doi.org/10.1016/ j.bj.2017.06.007.

Ingle, D. L., D. E. Bauman, and U. S. Garrigus. 1972. Lipogenesis in the ruminant: In vitro study of tissue sites, carbon source and reducing equivalent generation for fatty acid synthesis. J. Nutr. 102:609-616. https://doi.org/10.1093/jn/102.5.609.

Kenéz, Á., L. Ruda, S. Danicke, and K. Huber. 2019. Insulin signaling and insulin response in subcutaneous and retroperitoneal adipose tissue in Holstein cows during the periparturient period. J. Dairy Sci. 102:11718-11729. https://doi.org/10.3168/jds.2019-16873.

Khan, M. J., A. Hosseini, S. Burrell, S. M. Rocco, J. P. McNamara, and J. J. Loor. 2013. Change in subcutaneous adipose tissue metabolism and gene network expression during the transition period in dairy cows, including differences due to sire genetic merit. J. Dairy Sci. 96:2171-2182. https://doi.org/10.3168/jds.2012-5794.

Lanna, D. P., and D. E. Bauman. 1999. Effect of somatotropin, insulin, and glucocorticoid on lipolysis in chronic cultures of adipose tissue from lactating cows. J. Dairy Sci. 82:60-68. https://doi.org/ 10.3168/jds.S0022-0302(99)75209-4.

Li, S., A. Hosseini, M. Danes, C. Jacometo, J. Liu, and J. J. Loor. 2016. Essential amino acid ratios and mTOR affect lipogenic gene networks and miRNA expression in bovine mammary epithelial cells. J. Anim. Sci. Biotechnol. 7:44. https://doi.org/10.1186/ s40104-016-0104-x.

Liang, Y., A. S. Alharthi, R. Bucktrout, A. A. Elolimy, V. Lopreiato, I. Martinez-Cortés, C. Xu, C. Fernandez, E. Trevisi, and J. J. Loor. 2020. Body condition alters glutathione and nuclear factor erythroid 2-like 2 (NFE2L2)-related antioxidant network abundance in subcutaneous adipose tissue of periparturient Holstein cows. J. Dairy Sci. 103:6439-6453. https://doi.org/10.3168/jds.2019-17813.

Liang, Y., F. Batistel, C. Parys, and J. J. Loor. 2019a. Methionine supply during the periparturient period enhances insulin signaling, amino acid transporters, and mechanistic target of rapamycin pathway proteins in adipose tissue of Holstein cows. J. Dairy Sci. 102:4403-4414. https://doi.org/10.3168/jds.2018-15738.

Liang, Y., F. Batistel, C. Parys, and J. J. Loor. 2019b. Glutathione metabolism and nuclear factor erythroid 2-like 2 (NFE2L2)-related proteins in adipose tissue are altered by supply of ethyl-cellulose rumen-protected methionine in peripartal Holstein cows. J. Dairy Sci. 102:5530-5541. https://doi.org/10.3168/jds.2018-15687.

Liang, Y., N. Ma, D. N. Coleman, F. Liu, Y. Li, H. Ding, F. F. Cardoso, C. Parys, F. C. Cardoso, and J. J. Loor. 2021. Methionine and arginine supply alters abundance of amino acid, insulin signaling, and glutathione metabolism-related proteins in bovine subcutaneous adipose explants challenged with N-acetyl-d-sphingosine. Animals (Basel) 11:2114. https://doi.org/10.3390/ani11072114.

Loor, J. 2021. Methionine supplementation during a hydrogen peroxide challenge alters components of insulin signaling and antioxidant proteins in subcutaneous adipose explants from dairy cows. Mendeley Data, V1. https://doi.org/10.17632/d5xdrgdkjb.1.
Loor, J. J., M. Bionaz, and J. K. Drackley. 2013. Systems physiology in dairy cattle: Nutritional genomics and beyond. Annu. Rev. Anim. Biosci. 1:365-392. https://doi.org/10.1146/annurev-animal $-031412-103728$

Lopreiato, V., A. Hosseini, F. Rosa, Z. Zhou, A. Alharthi, E. Trevisi, and J. J. Loor. 2018. Dietary energy level affects adipose depot mass but does not impair in vitro subcutaneous adipose tissue response to short-term insulin and tumor necrosis factor- $\alpha$ challenge in nonlactating, nonpregnant Holstein cows. J. Dairy Sci. 101:10206-10219. https://doi.org/10.3168/jds.2018-14389.

Lopreiato, V., M. Vailati-Riboni, A. Bellingeri, I. Khan, G. Farina, C. Parys, and J. J. Loor. 2019. Inflammation and oxidative stress transcription profiles due to in vitro supply of methionine with or without choline in unstimulated blood polymorphonuclear leukocytes from lactating Holstein cows. J. Dairy Sci. 102:10395-10410. https://doi.org/10.3168/jds.2019-16413.

$\mathrm{Lu}$, S. C. 2013. Glutathione synthesis. Biochim. Biophys. Acta 1830:3143-3153. https://doi.org/10.1016/j.bbagen.2012.09.008.

Lushchak, V. I. 2012. Glutathione homeostasis and functions: Potential targets for medical interventions. J. Amino Acids 2012:736837. https://doi.org/10.1155/2012/736837.

Ma, Y. F., Z. H. Wu, M. Gao, and J. J. Loor. 2018b. Nuclear factor erythroid 2-related factor 2-antioxidant activation through the action of ataxia telangiectasia-mutated serine/threonine kinase is essential to counteract oxidative stress in bovine mammary epithelial cells. J. Dairy Sci. 101:5317-5328. https://doi.org/10.3168/jds .2017-13954.

Ma, Y. F., Z. H. Wu, M. Gao, and J. J. Loor. 2018c. Nuclear factor erythroid 2-related factor 2 antioxidant response element pathways protect bovine mammary epithelial cells against $\mathrm{H}_{2} \mathrm{O}_{2}$-induced oxidative damage in vitro. J. Dairy Sci. 101:5329-5344. https://doi .org/10.3168/jds.2017-14128.

Ma, Y. F., L. Zhao, D. N. Coleman, M. Gao, and J. J. Loor. 2019. Tea polyphenols protect bovine mammary epithelial cells from hydrogen peroxide-induced oxidative damage in vitro by activating NFE2L2/HMOX1 pathways. J. Dairy Sci. 102:1658-1670. https:// doi.org/10.3168/jds.2018-15047.

Ma, Y. F., L. Zhao, M. Gao, and J. J. Loor. 2018a. Tea polyphenols protect bovine mammary epithelial cells from hydrogen peroxideinduced oxidative damage in vitro. J. Anim. Sci. 96:4159-4172. https://doi.org/10.1093/jas/sky278.

Martinov, M. V., V. M. Vitvitsky, R. Banerjee, and F. I. Ataullakhanov. 2010. The logic of the hepatic methionine metabolic cycle. Biochim. Biophys. Acta 1804:89-96. https://doi.org/10.1016/j .bbapap. 2009.10.004.

McFadden, J. W., and B. A. Corl. 2009. Activation of AMP-activated protein kinase (AMPK) inhibits fatty acid synthesis in bovine mammary epithelial cells. Biochem. Biophys. Res. Commun. 390:388-393. https://doi.org/10.1016/j.bbrc.2009.09.017.

McNamara, J. P., J. H. Harrison, R. L. Kincaid, and S. S. Waltner. 1995. Lipid metabolism in adipose tissue of cows fed high fat diets during lactation. J. Dairy Sci. 78:2782-2796. https://doi.org/10 .3168/jds.S0022-0302(95)76909-0.

McNamara, J. P., and K. Huber. 2018. Metabolic and endocrine role of adipose tissue during lactation. Annu. Rev. Anim. Biosci. 6:177195. https://doi.org/10.1146/annurev-animal-030117-014720.

Minuti, A., M. Bionaz, V. Lopreiato, N. A. Janovick, S. L. RodriguezZas, J. K. Drackley, and J. J. Loor. 2020. Prepartum dietary energy intake alters adipose tissue transcriptome profiles during the periparturient period in Holstein dairy cows. J. Anim. Sci. Biotechnol. 11:1. https://doi.org/10.1186/s40104-019-0409-7.

Moisá, S. J., P. Ji, J. K. Drackley, S. L. Rodriguez-Zas, and J. J. Loor. 2017. Transcriptional changes in mesenteric and subcutaneous adipose tissue from Holstein cows in response to plane of dietary energy. J. Anim. Sci. Biotechnol. 8:85. https://doi.org/10.1186/ s40104-017-0215-z.

NRC. 2001. Nutrient Requirements of Dairy Cattle. 7th rev. ed. National Academies Press.

Pedernera, M., P. Celi, S. C. García, H. E. Salvin, I. Barchia, and W. J. Fulkerson. 2010. Effect of diet, energy balance and milk pro- 
duction on oxidative stress in early-lactating dairy cows grazing pasture. Vet. J. 186:352-357. https://doi.org/10.1016/j.tvjl.2009 .09 .003 .

Petrache, I., T. R. Medler, A. T. Richter, K. Kamocki, U. Chukwueke, L. Zhen, Y. Gu, J. Adamowicz, K. S. Schweitzer, W. C. Hubbard, E. V. Berdyshev, G. Lungarella, and R. M. Tuder. 2008. Superoxide dismutase protects against apoptosis and alveolar enlargement induced by ceramide. Am. J. Physiol. Lung Cell. Mol. Physiol. 295:L44-L53. https://doi.org/10.1152/ajplung.00448.2007.

Sordillo, L. M., and S. L. Aitken. 2009. Impact of oxidative stress on the health and immune function of dairy cattle. Vet. Immunol. Immunopathol. 128:104-109. https://doi.org/10.1016/j.vetimm.2008 .10 .305 .

Sordillo, L. M., and W. Raphael. 2013. Significance of metabolic stress, lipid mobilization, and inflammation on transition cow disorders. Vet. Clin. North Am. Food Anim. Pract. 29:267-278. https://doi .org/10.1016/j.cvfa.2013.03.002.

Sun, F., Y. Cao, C. Cai, S. Li, C. Yu, and J. Yao. 2016. Regulation of nutritional metabolism in transition dairy cows: Energy homeostasis and health in response to post-ruminal choline and methionine. PLoS One 11:e0160659. https://doi.org/10.1371/journal.pone .0160659

Sun, X., X. Li, H. Jia, J. J. Loor, R. Bucktrout, Q. Xu, Y. Wang, X. Shu, J. Dong, R. Zuo, L. Yang, G. Liu, and X. Li. 2019. Effect of heat-shock protein B7 on oxidative stress in adipocytes from preruminant calves. J. Dairy Sci. 102:5673-5685. https://doi.org/ $10.3168 /$ jds.2018-15726.

Vailati-Riboni, M., M. Kanwal, O. Bulgari, S. Meier, N. V. Priest, C. R. Burke, J. K. Kay, S. McDougall, M. D. Mitchell, C. G. Walker, M. Crookenden, A. Heiser, J. R. Roche, and J. J. Loor. 2016. Body condition score and plane of nutrition prepartum affect adipose tissue transcriptome regulators of metabolism and inflammation in grazing dairy cows during the transition period. J. Dairy Sci. 99:758-770. https://doi.org/10.3168/jds.2015-10046.
Vailati-Riboni, M., T. Xu, B. Qadir, R. Bucktrout, C. Parys, and J. J. Loor. 2019. In vitro methionine supplementation during lipopolysaccharide stimulation modulates immunometabolic gene network expression in isolated polymorphonuclear cells from lactating Holstein cows. J. Dairy Sci. 102:8343-8351. https://doi.org/10.3168/ jds.2018-15737.

Vallabhapurapu, S., and M. Karin. 2009. Regulation and function of NF- $\kappa$ B transcription factors in the immune system. Annu. Rev Immunol. 27:693-733. https://doi.org/10.1146/annurev.immunol .021908 .132641 .

Xu, Q., Y. Fan, J. J. Loor, Y. Liang, X. Sun, H. Jia, C. Zhao, and C. Xu. 2021. Adenosine 5'-monophosphate-activated protein kinase ameliorates bovine adipocyte oxidative stress by inducing antioxidant responses and autophagy. J. Dairy Sci. 104:4516-4528. https: //doi.org/10.3168/jds.2020-18728.

Zhang, B., M. Li, W. Yang, J. J. Loor, Y. Liang, S. Wang, Y. Zhao, H. Guo, X. Ma, L. Yu, and C. Xu. 2020. Mitochondrial dysfunction and endoplasmic reticulum stress in calf hepatocytes are associated with fatty acid-induced ORAI calcium release-activated calcium modulator 1 signaling. J. Dairy Sci. 103:11945-11956. https: //doi.org/10.3168/jds.2020-18684.

Zhao, D., J. Yang, and L. Yang. 2017. Insights for oxidative stress and mTOR signaling in myocardial ischemia/reperfusion injury under diabetes. Oxid. Med. Cell. Longev. 2017:6437467. https://doi.org/ $10.1155 / 2017 / 6437467$.

Zhou, Z., O. Bulgari, M. Vailati-Riboni, E. Trevisi, M. A. Ballou, F. C. Cardoso, D. N. Luchini, and J. J. Loor. 2016. Rumen-protected methionine compared with rumen-protected choline improves immunometabolic status in dairy cows during the peripartal period. J. Dairy Sci. 99:8956-8969. https://doi.org/10.3168/jds.2016 $-10986$. 